\title{
GENETIC EVALUATION OF RED CHITTAGONG CATTLE IN BANGLADESH
}

\author{
F. Ferdous ${ }^{1}$, M.P. Choudhury ${ }^{2}$, M.O. Faruque $^{3}$, M.M. Hossain ${ }^{1}$ and \\ A.K.F.H. Bhuiyan ${ }^{1 *}$ \\ ${ }^{1}$ Department of Animal Breeding and Genetics, Bangladesh Agricultural University, \\ Mymensingh 2202, \\ ${ }^{2}$ Goat and Sheep Production Research Division, Bangladesh Livestock Research Institute, \\ Savar, Dhaka-1341, \\ ${ }^{3}$ Animal Research Division, Bangladesh Institute of Research and Training on Applied \\ Nutrition (BIRTAN), Sher-e-Bangla Nagar, Dhaka-1207,
}

\begin{abstract}
The current study was carried out using data of the Nucleus Herd and Community Herd of Red Chittagong Cattle (RCC) established through USDA funded Red Chittagong Cattle project under the Department of Animal Breeding and Genetics, BAU, Mymensingh. Data on 151 calves and 75 lactating cows were analyzed. The estimated heritability values were $0.45 \pm 0.05$ for birth weight, $0.48 \pm 0.05$ for weaning weight, $0.41 \pm$ 0.08 for pre-weaning daily gain, $0.47 \pm 0.06$ for lactation length, $0.43 \pm$ 0.07 for lactation milk yield and $0.35 \pm 0.09$ for average daily milk yield. The highest Breeding Value (BV) were for birth weight $(3.2 \mathrm{~kg})$, weaning weight $(24.46 \mathrm{~kg})$, pre-weaning daily gain $(82.39 \mathrm{~g})$, lactation length (52.25 days), lactation milk yield $(186.04 \mathrm{~kg})$ and average daily milk yield $(0.66 \mathrm{~kg})$. The minimum and maximum phenotypic index values by using phenotypic parameters were for growth traits (1196.24 and 4713.24) and milk production traits (8573.93 and 40670.81). The minimum and maximum genetic index values by using breeding values were for growth traits (1812.49 and 2870.21) and milk production traits (-1812.49 and 2870.21 ). All the estimated index values can be used in animal selection and breeding programs for RCC improvement and similar index selection can be applied for other indigenous cattle development programs in Bangladesh or elsewhere.
\end{abstract}

Keywords: RCC, Herzitability, BV, Phenotypic index and Genetic index

\section{INTRODUCTION}

Cattle of Bangladesh are mostly non-descriptive indigenous type along with fewer exotic pure breeds and their crosses with indigenous cattle and these are the

\footnotetext{
*Corresponding author: bhuiyanbau@gmail.com
} 
component of cattle genetic resource of Bangladesh. The indigenous cattle constitute nearly $90 \%$ of the total population. (Afroz et al., 2011).The Red Chittagong Cattle (RCC) is an important cattle breed genotype of Bangladesh. They have been originated from greater Chittagong district of Bangladesh. The Red Chittagong breed is found more or less everywhere in Chittagong district but with a relatively higher concentration in the Thanas of Chandonaish, Anawara, Potia, Raozan, Rangunia, Mirersarai, Hathazari , Bashkhali and Photicshary and is rare in other parts of the country. This breed of cattle has their distinct identity that distinguishes it from other cattle of Bangladesh (Bhuiyan, 2004).The coat color of RCC is red (deep as well as light), their muzzle and hoof are whitish in color and small headed, its body size is comparatively small but physical condition is very strong and stout (Habib et al., 2003). Furthermore, they are reputed to give birth every year, which is considered a unique characteristic of RCC (Habib et al., 2010). It is not yet recognized as a breed is considered to be a valuable indigenous bovine genetic resource of Bangladesh with many attributes better than other available indigenous types and is readily distinguishable from others due to its distinct phenotypic features (Bhuiyan et al., 2007).

Heritability $\left(h^{2}\right)$ estimation is the pre-requisite to estimate the genetic merit of individual animal constituting population and they are essential population parameters required in the design and application of practical animal breeding programme. The estimation of breeding value of female stocks in a herd is of utmost importance since the selection of superior female results into the increased production in the present generation as well as this also helps in taking decisions for replacement and culling in a herd (Shakhawat, 2006).The genetic trend, which is the change in production per animal per unit of time due to change in mean breeding value of the animals would be an indicator to determine the direction of change brought about as a result of any kind of breeding program operated (Bhuiyan et al., 2003).

\section{MATERIALS AND METHODS}

The data of the study were collected from the Nucleus Herd of United States Department of Agriculture (USDA) funded Red Chittagong Cattle (RCC) project carried out at the Department of Animal Breeding and Genetics, Bangladesh Agricultural University (BAU), Mymensingh and community herd Char Jailkhana under Mymensingh district, Bangladesh during the period from 2005 to 2011. For genetic analysis of growth traits, birth weight, weaning weight, pre-weaning daily gain was taken. For genetic analysis of milk production traits, data on seventy five (75) cows were taken into consideration. Milking was done twice in a day. The whole year was divided into three seasons both for growth trait and milk trait data to take an unbiased account of environmental variation. The three seasons were summer (March-June), rainy (July-October), and winter (November-February).The RCC 
Nucleus herd at BAU (site-1) is situated 4.5 kilometer $(\mathrm{km})$ apart from Mymensingh city. It lies between $24^{\circ} 30^{\prime}$ and $25^{\circ} 10^{\prime}$ North latitude and $90^{\circ} 15^{\prime}$ and $91^{\circ} 15^{\prime}$ East longitudes. The community RCC herd (site-2) is situated 2.0 kilometer $(\mathrm{km})$ apart in the North side from Mymensingh city lies between $24^{\circ} 77^{\prime}$ and $24^{\circ} 78^{\prime}$ North latitude and $90^{\circ} 39^{\prime}$ and $90^{\circ} 41^{\prime}$ East longitudes (Fig.1).

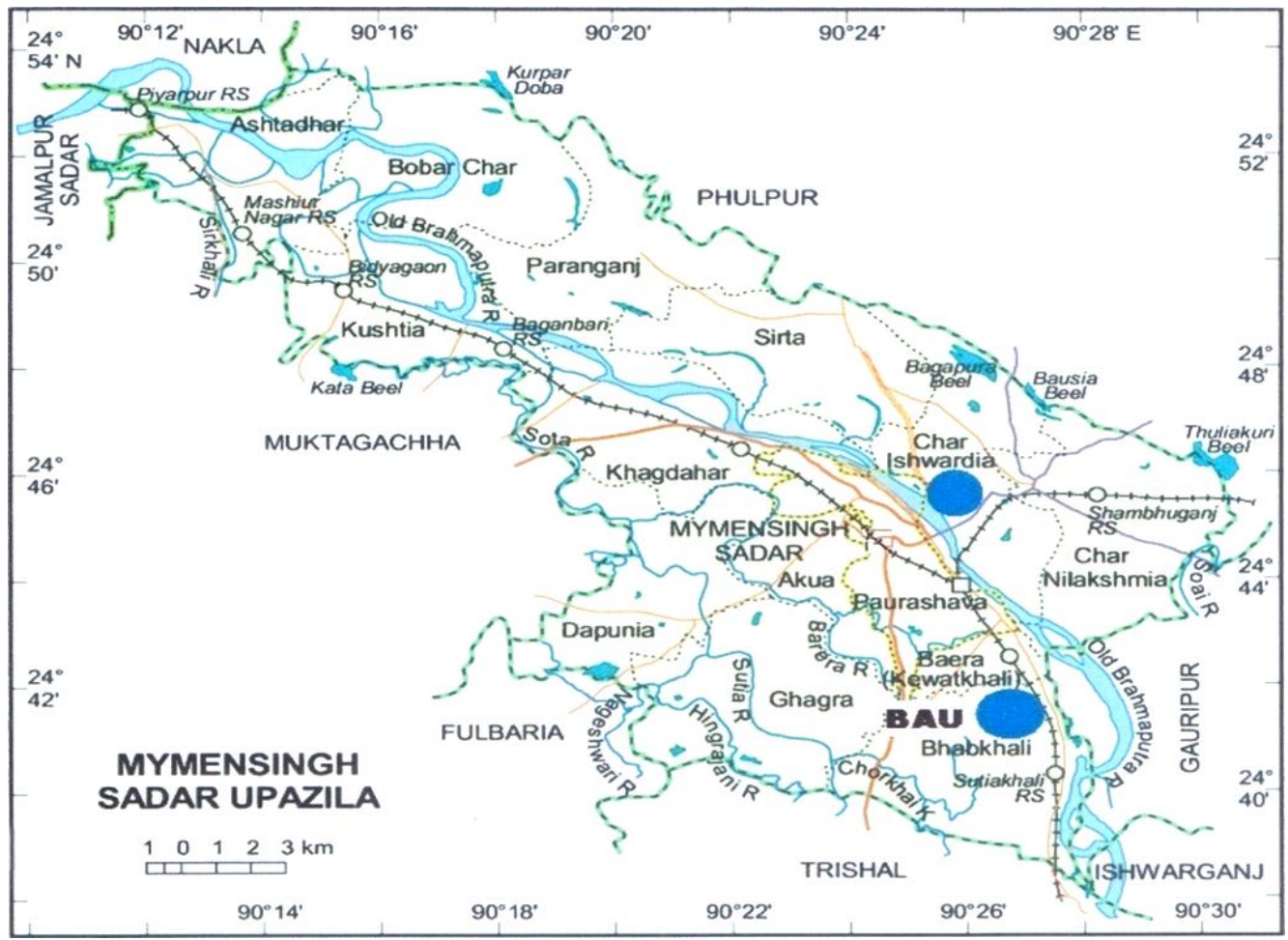

Figure 1. Data collection site at Mymensingh district (herd-1 and herd-2) indicated by blue circle mark

Feeding and management practices followed at the nucleus herd were almost uniform throughout the years. The animals were stall-fed and concentrate feeds were supplied twice daily in the morning and evening. Annual fodder maize and perennial fodder German and road side grasses were fed in fresh condition to the cattle and calves. Rice straw was used as bulk basal feed with some green grasses. During the crisis period (e.g. in winter when there is scarcity of green grass), the animals were fed with Urea Molasses Straw (UMS). Regular vaccination, medication, heat detection were performed. Animal are reared in community herd mainly by pasturing in fallow land and harvested crop field. Sometimes farmers supply concentrate with straw to the animal. The weight at birth of the calf was expressed in kilogram $(\mathrm{kg})$. The birth weight was taken with a balance directly just after birth. Weaning weight was taken by balance at weaning age and expressed in $\mathrm{kg}$. Growth rate of animals before 
weaning was estimated. Pre-weaning growth rate was estimated (g/day) on the basis of exact weaning age of individuals. In this study lactation length was measured in days. The number of days from first milking to the end of milking of a cow is called lactation length. Total lactation milk yield was expressed in $\mathrm{kg}$. The total quantity of milk produced throughout the lactation was taken as lactation yield. The average daily yield is the total milk yield in lactation divided by the total number of days in that lactation and was measured in $\mathrm{kg}$.

\section{Data structure}

Data structures are presented in Table 1 and Table 2.

Table 1. Data structure for growth traits

\begin{tabular}{|c|c|c|c|c|c|}
\hline \multirow{2}{*}{ Trait } & \multirow{2}{*}{$\mathrm{N}$} & \multicolumn{2}{|c|}{ Sex } & \multicolumn{2}{|c|}{ Herd } \\
\hline & & Male & Female & Nucleus & Community \\
\hline BWT & 151 & 77 & 74 & 75 & 76 \\
\hline WWT & 151 & 77 & 74 & 75 & 76 \\
\hline PWDG & 151 & 77 & 74 & 75 & 76 \\
\hline
\end{tabular}

BWT $=$ Birth weight, WWT $=$ Weaning weight, PWDG $=$ Pre-weaning daily gain, $\mathrm{N}=$ No. of observation

Table 2. Data structure for milk production traits

\begin{tabular}{l|c|r|c|c|c|c|c|c|c}
\hline \multirow{2}{*}{ Trait } & \multirow{2}{*}{ N } & \multicolumn{7}{c|}{ Parity } & \multicolumn{2}{c}{ Herd } \\
\cline { 3 - 10 } & & 1 & 2 & 3 & 4 & 5 & 6 & Nucleus & Community \\
\hline ADMY & 89 & 18 & 36 & 17 & 8 & 3 & 7 & 55 & 34 \\
LL & 89 & 18 & 36 & 17 & 8 & 3 & 7 & 55 & 34 \\
LMY & 89 & 18 & 36 & 17 & 8 & 3 & 7 & 55 & 34 \\
\hline
\end{tabular}

ADMY $=$ Average daily milk yield, $\mathrm{LL}=$ Lactation length, $\mathrm{LMY}=$ Lactation milk

Yield, $\mathrm{N}=$ No. of observation.

\section{Data analyses}

Simple means and standard errors of the studied traits were analyzed by using Statistical Package for Social Science (SPSS 16.0) program. For estimating heritability $\left(\mathrm{h}^{2}\right)$, VCE-4.2.5 (Groeneveld, 1998) computer software was used.

All analyses were done using a single trait animal model where animal's additive genetic effect was the only random factor and sex of the animal, parity of mother, season of birth and year of birth as fixed factors.

The statistical model in matrix notation was:

$\mathrm{Y}=\mathrm{Xb}+\mathrm{Za}+\mathrm{Wc}+\mathrm{e}$ 
Where,

$\mathrm{Y}=$ Vector of observation.

$\mathrm{X}, \mathrm{Z}$ and $\mathrm{W}=$ Known incidence matrices that were associated with levels of $b, a, c$ with Y.

$\mathrm{B}=$ Unknown vector of fixed effects (i.e. sex of calf, parity of dam, year of birth and season of birth).

$\mathrm{a}=$ Unknown vector of breeding value.

$\mathrm{c}=$ Unknown vector of permanent environmental effect.

$\mathrm{e}=$ Vector of residual effects.

The pre-weaning growth rate was calculated from weight data between birth and weaning. The statistical comparison was done by using SPSS 16.0 computer package program.

\section{Heritability estimation}

Heritability and variance components were estimated for birth weight, weaning weight, pre-weaning daily gain, lactation length, lactation milk yield and average daily milk yield. Heritability $\left(\mathrm{h}^{2}\right)=\frac{\delta^{2} A}{\delta^{2} P}=\frac{\delta^{2}{ }_{A}}{\delta^{2}{ }_{G}+\delta^{2} E}=\frac{\delta^{2} A}{\delta^{2} A^{+} \delta^{2}{ }^{+}+\delta^{2}{ }_{I+\delta^{2}}{ }_{E}}$

Where,

$\delta^{2}{ }_{A}=$ Additive genetic variance

$\delta^{2}{ }_{G}=$ Genotypic variance

$\delta^{2}{ }_{D}=$ Variance due to dominant gene action

$\delta^{2}{ }_{I}=$ Variance due to epistatic gene action

$\delta^{2}{ }_{E}=$ Variance due to environmental variation

$\delta^{2}{ }_{P}=$ Total phenotypic variance

\section{Breeding value estimation}

Breeding value of animals for the traits was estimated using Best Linear Unbiased Prediction (BLUP) methodology. The BLUP in turn was carried out by computer program prediction and estimation (PEST-3.1) proposed by Groeneveld et al, (1998).

\section{Ranking of animals}

In this study, animals were ranked according to the predicted breeding values. The animals were evaluated for six production traits viz. birth weight, weaning weight, pre-weaning daily gain, average daily milk yield, lactation length and lactation milk yield.

\section{Genetic evaluation of RCC for multiple traits}

This was done by selection index method using phenotypic values, breeding values, and relative economic values of considered traits. The two selection indices were constructed as follows: 
1. The net genetic improvement which can be brought about by selecting among a group of animals is the sum of the genetic gains made for the several traits which have economic importance. It is logical to weight the gain made for each trait $\left(\mathrm{G}_{\mathrm{i}}\right)$ by the relative economic value of that trait $\left(\mathrm{a}_{\mathrm{i}}\right)$. Thus the average phenotypic index $\left(\mathrm{I}_{\mathrm{P}}\right)$ value of an animal was calculated as:

$$
\mathrm{I}_{\mathrm{P}}=\mathrm{a}_{1} \overline{\mathrm{G}}_{1}+\mathrm{a}_{2} \overline{\mathrm{G}}_{2}+\mathrm{a}_{3} \overline{\mathrm{G}_{3}}+\ldots \ldots \ldots \ldots \ldots+\mathrm{a}_{\mathrm{n}} \mathrm{G}_{\mathrm{n}}
$$

$a_{i}=$ relative economic value of particular trait (hypothetical and constant values for the traits were used)

$$
\mathrm{Gi}=\text { phenotypic value of an animal for a particular } \mathrm{z} \text { trait }
$$

2. An animal's genotype for a given trait may be defined as the sum of average (strictly additive) effects of its genes which influence that trait. Thus the aggregate genotypic index $\left(\mathrm{I}_{\mathrm{G}}\right)$ value of an animal was calculated as:

$$
\mathrm{I}_{\mathrm{G}}=\mathrm{a}_{1} \mathrm{G}_{1}+\mathrm{a}_{2} \mathrm{G}_{2}+\mathrm{a}_{3} \mathrm{G}_{3}+\ldots \ldots \ldots \ldots+\mathrm{a}_{\mathrm{n}} \mathrm{G}_{\mathrm{n}}
$$

$a_{i}=$ relative economic value of particular trait(hypothetical and constant values for the traits were used)

$$
\mathrm{Gi}=\text { breeding value of an animal for a particular trait }
$$

Relative economic value for BWT, WWT and PWDG were taken as 40, 30 and 30 respectively. Relative economic value for LL, LMY and ADMY were taken as 35, 30 and 35 respectively.

\section{RESULTS}

\section{Heritability}

The data of 151 RCC were analyzed using general linear model (univariate). The model with highest $\mathrm{R}^{2}$ value was treated as final model. The estimated heritability for BWT, WWT and PWDG were $0.45 \pm 0.05,0.48 \pm 0.05$ and $0.41 \pm 0.08$ (Table 3 and Table 4).

Table 3. Summary of analyses of growth traits

\begin{tabular}{l|l|l|l}
\hline \multirow{2}{*}{ Factor } & \multicolumn{3}{l}{ Trait } \\
\cline { 2 - 4 } & BWT & WWT & PWDG \\
\hline Sex & $* *$ & NS & NS \\
Season of birth & $*$ & NS & $* * *$ \\
Year of birth & NS & $* * *$ & NS \\
Parity of dam & NS & NS & NS \\
Herd & NS & $* * *$ & $* *$ \\
$R^{2}$ of the model & 0.984 & 0.931 & 0.898 \\
\hline
\end{tabular}

BWT $=$ Birth weight, WWT $=$ Weaning weight, $\mathrm{PWDG}=$ Pre-weaning daily gain, NS = not significant $(P>0.05),(*)=$ significant $(P<0.05),(* *)=$ highly significant $(P<0.01),(* * *)=$ highly significant $(P<0.001)$. 
Table 4. Covariance components and heritability of growth traits

\begin{tabular}{|c|c|c|c|c|}
\hline \multirow{2}{*}{ Trait } & \multirow{2}{*}{$\mathrm{N}$} & \multicolumn{2}{|c|}{ (Co)variance matrices } & \multirow{2}{*}{$\mathrm{h}^{2} \pm \mathrm{SE}$} \\
\hline & & Additive genetic & Common environment & \\
\hline BWT & 151 & 1.920 & 0.465 & $0.45 \pm 0.05$ \\
\hline WWT & 151 & 112.841 & 928.860 & $0.48 \pm 0.05$ \\
\hline PWDG & 151 & 1517.129 & 626.990 & $0.41 \pm 0.08$ \\
\hline
\end{tabular}

\section{Breeding value}

Breeding value of $151 \mathrm{RCC}$ for body weight and growth traits was estimated and animals were ranked according to their genetic merit. -

\section{Milk production traits}

\section{Lactation length}

Mean lactation length (day) of cows according to season of birth, year of birth, parity of dam and herd are shown in Table 5. The mean lactation length of RCC was 212.19 \pm 9.02 days. The effect of herd was significant $(\mathrm{P}<0.05)$ on lactation length.

Table 5. Mean lactation length (day) of calves according to season of birth, year of birth, parity of dam and herd

\begin{tabular}{|c|c|c|c|c|}
\hline Factor & & $\mathrm{N}$ & Mean \pm SE & Level of significance \\
\hline \multirow{3}{*}{$\begin{array}{l}\text { Season of } \\
\text { birth }\end{array}$} & Summer & 37 & $211.82 \pm 11.06$ & \multirow{3}{*}{ NS } \\
\hline & Rainy & 16 & $221.08 \pm 11.20$ & \\
\hline & Winter & 22 & $203.66 \pm 11.76$ & \\
\hline \multirow{4}{*}{$\begin{array}{l}\text { Year of } \\
\text { birth }\end{array}$} & 2005 & 16 & $207.59 \pm 9.65$ & \multirow{4}{*}{ NS } \\
\hline & 2006 & 18 & $212.34 \pm 10.60$ & \\
\hline & 2007 & 39 & $201.33 \pm 9.37$ & \\
\hline & 2008 & 02 & $227.49 \pm 30.40$ & \\
\hline \multirow{6}{*}{$\begin{array}{l}\text { Parity of } \\
\text { dam }\end{array}$} & $1 \mathrm{st}$ & 10 & $235.98 \pm 16.47$ & \multirow{6}{*}{ NS } \\
\hline & $2 \mathrm{nd}$ & 33 & $197.18 \pm 9.40$ & \\
\hline & $3 \mathrm{rd}$ & 15 & $217.10 \pm 11.79$ & \\
\hline & 4th & 09 & $209.68 \pm 13.22$ & \\
\hline & 5 th & 02 & $205.79 \pm 29.98$ & \\
\hline & 6th & 06 & $207.39 \pm 18.82$ & \\
\hline \multirow{2}{*}{ Herd } & Community & 21 & $196.73 \pm 9.69$ & \multirow[t]{2}{*}{ * } \\
\hline & Nucleus & 54 & $227.65 \pm 13.70$ & \\
\hline
\end{tabular}

NS = not significant $(P>0.05),(*)=$ significant $(P<0.05), \quad \mathrm{N}=$ No. of observation, $\mathrm{SE}=$ Standard error. 


\section{Lactation Milk Yield}

Mean lactation milk yield (liter) and average daily milk yield of calves according to season of birth, year of birth, parity of dam and herd are shown in Table 6 and Table 7. The mean lactation milk yield of RCC was $579.11 \pm 38.89$ liters. The effect of herd and parity of dam was significant $(\mathrm{P}<0.05)$ on lactation length.

Table 6. Mean lactation milk yield (liter) of calves according to season of birth, year of birth, parity of dam and herd

\begin{tabular}{ll|l|l|l}
\hline Factor & & N & Mean \pm SE & Level of significance \\
\hline \multirow{2}{*}{$\begin{array}{l}\text { Season of } \\
\text { birth }\end{array}$} & Summer & 37 & $575.66 \pm 47.64$ & \\
& Rainy & 16 & $609.67 \pm 48.27$ & NS \\
& Winter & 22 & $551.99 \pm 50.68$ & \\
\multirow{2}{*}{$\begin{array}{l}\text { Year of } \\
\text { birth }\end{array}$} & 2005 & 16 & $556.62 \pm 41.57$ & \\
& 2006 & 18 & $604.60 \pm 45.69$ & NS \\
& 2007 & 39 & $585.67 \pm 40.39$ & \\
& 2008 & 02 & $569.54 \pm 130.99$ & \\
\multirow{3}{*}{$\begin{array}{l}\text { Parity of } \\
\text { dam }\end{array}$} & 3rt & 10 & $561.49^{\mathrm{ab}} \pm 70.95$ & \\
& 4th & 33 & $484.48^{\mathrm{b}} \pm 40.49$ & \\
& 5th & 15 & $600.98^{\mathrm{ab}} \pm 50.79$ & $*$ \\
& 6th & 09 & $682.05^{\mathrm{a}} \pm 56.97$ & \\
Herd & Community & 21 & $594.39^{\mathrm{a}} \pm 129.18$ & \\
& Nucleus & 54 & $551.24^{\mathrm{ab}} \pm 81.12$ & \\
\hline
\end{tabular}

NS = not significant $(P>0.05),(*)=$ significant $(P<0.05), \mathrm{N}=$ No. of observation, $\mathrm{SE}=$ Standard error.

\section{Average Daily Milk Yield}

The average daily milk yield of RCC was $2.67 \pm 0.13$ liters. The effect of parity of dam was highly significant $(\mathrm{P}<0.01)$ on average daily milk yield. The effect of herd was also highly significant $(\mathrm{P}<0.001)$ on average daily milk yield (Table 7$)$. 
Table 7. Mean average daily milk yield (liter) of calves according to season of birth, year of birth, parity of dam and herd

\begin{tabular}{|c|c|c|c|c|}
\hline Factor & & $\mathrm{N}$ & Mean \pm SE & Level of significance \\
\hline \multirow{3}{*}{$\begin{array}{l}\text { Season of } \\
\text { birth }\end{array}$} & Summer & 37 & $2.68 \pm 0.16$ & \multirow{3}{*}{ NS } \\
\hline & Rainy & 16 & $2.69 \pm 0.16$ & \\
\hline & Winter & 22 & $2.65 \pm 0.17$ & \\
\hline \multirow{4}{*}{$\begin{array}{l}\text { Year of } \\
\text { birth }\end{array}$} & 2005 & 16 & $2.69 \pm 0.14$ & \multirow{4}{*}{ NS } \\
\hline & 2006 & 18 & $2.86 \pm 0.15$ & \\
\hline & 2007 & 39 & $2.96 \pm 0.13$ & \\
\hline & 2008 & 02 & $2.19 \pm 0.43$ & \\
\hline \multirow{6}{*}{$\begin{array}{l}\text { Parity of } \\
\text { dam }\end{array}$} & $1^{\text {st }}$ & 10 & $2.12^{\mathrm{abc}} \pm 0.23$ & \multirow{6}{*}{$* *$} \\
\hline & $2^{\text {nd }}$ & 33 & $2.52^{\mathrm{c}} \pm 0.13$ & \\
\hline & $3^{\text {rd }}$ & 15 & $2.79^{\mathrm{bc}} \pm 0.17$ & \\
\hline & $4^{\text {th }}$ & 09 & $3.29^{\mathrm{ab}} \pm 0.19$ & \\
\hline & $5^{\text {th }}$ & 02 & $2.74^{\mathrm{a}} \pm 0.42$ & \\
\hline & $6^{\text {th }}$ & 06 & $2.57^{\mathrm{ab}} \pm 0.27$ & \\
\hline \multirow{2}{*}{ Herd } & Community & 21 & $3.33 \pm 0.14$ & \multirow{2}{*}{$* * *$} \\
\hline & Nucleus & 54 & $2.02 \pm 0.19$ & \\
\hline
\end{tabular}

NS $=$ not significant $(P>0.05), \quad(* *)=$ highly significant $(P<0.01),(* * *)=$ highly significant $(P<0.001)$, $\mathrm{N}=$ No. of observation, $\mathrm{SE}=$ Standard error.

\section{Heritability}

The data of 75 RCC were analyzed using general linear model (univariate). The model with highest $\mathrm{R}^{2}$ value was treated as final model. Summary of analysis of milk production traits are shown in Table 8. Co-variance component and heritability of milk production traits are also presented in Table 9. The estimated heritability for LL, LMY and ADMY were $0.47 \pm 0.06,0.43 \pm 0.07$ and $0.35 \pm 0.09$.

Table 8 . Summary of analysis of milk production traits

\begin{tabular}{|c|c|c|c|}
\hline \multirow{2}{*}{ Factor } & \multicolumn{3}{|l|}{ Trait } \\
\hline & LL & LMY & ADMY \\
\hline Season of birth & NS & NS & NS \\
\hline Year of birth & NS & NS & NS \\
\hline Parity of dam & NS & $*$ & $* *$ \\
\hline Herd & $*$ & $*$ & $* * *$ \\
\hline$R^{2}$ of the model & 0.976 & 0.935 & 0.969 \\
\hline
\end{tabular}

$\mathrm{LL}=$ Lactation length, $\mathrm{LMY}=$ Lactation milk yield, $\mathrm{ADMY}=$ Average daily milk yield, $\mathrm{NS}=$ not significant $(P>0.05),(*)=$ significant $(P<0.05),(* *)=$ highly significant $(P<0.01),(* * *)=$ highly significant $(P<0.001)$. 
Table 9. (Co) variance component and heritability of milk production traits

\begin{tabular}{l|lllll}
\hline \multirow{2}{*}{ Trait } & \multicolumn{3}{|l|}{$(\mathrm{Co})$ variance matrices } & \multirow{2}{*}{$\mathrm{h}^{2} \pm \mathrm{SE}$} \\
\cline { 2 - 4 } & $\mathrm{N}$ & Additive genetic & Common environment & \\
\hline LL & 75 & 628.62 & 95.89 & $0.47 \pm 0.06$ \\
LMY & 75 & 11656.83 & 3962.56 & $0.43 \pm 0.07$ \\
ADMY & 75 & 0.13 & 0.11 & $0.35 \pm 0.09$ \\
\hline
\end{tabular}

$\mathrm{LL}=$ Lactation length, $\mathrm{LMY}=$ Lactation milk yield, ADMY= Average daily milk yield, $\mathrm{N}=$ No. of observation, $\mathrm{SE}=$ Standard error, $\mathrm{h}^{2}=$ Heritability .

\section{Breeding value}

Breeding value of $75 \mathrm{RCC}$ for milk production traits was estimated and animals were ranked according to their genetic merit.

\section{Multi-trait genetic evaluation of RCC by using selection index}

Estimation of relative economic values of various traits of RCC is yet to be done in Bangladesh. So, an assumption of relative economic values for BWT, WWT and PWDG were taken as 40, 30 and 30 respectively. Relative economic values for LL, LMY and ADMY were taken as 35, 30 and 35 respectively.

\section{Selection index for multiple traits and ranking of animals}

\section{Growth traits}

Phenotypic index value by using phenotypic data of particular trait for growth traits ranged from 1196.24 to 4713.24. Animal bearing ID 178 obtained highest index value that had highest birth weight, weaning weight and pre-weaning daily gain as $13.50 \mathrm{~kg}, 138.75 \mathrm{~kg}$ and $0.36 \mathrm{~g} / \mathrm{d}$, respectively. On the other hand, animal bearing ID 71 obtained lowest index value that had lowest birth weight, weaning weight and preweaning daily gain as $13.00 \mathrm{~kg}, 22.50 \mathrm{~kg}$ and $0.04 \mathrm{~g} / \mathrm{d}$, respectively. Genetic index value by using breeding value of particular trait for growth traits ranged from 1812.49 to 2870.21 . Animal bearing ID 196 obtained highest index value and ID 229 obtained lowest index value.

\section{Milk production traits}

Phenotypic index value by using phenotypic data of particular trait for milk traits ranged from 8573.93 to 40670.81 . Animal bearing ID 74 obtained highest index value that had highest lactation length, lactation milk yield and average daily milk yield as 304.00 days, 997.20 liters and 3.28 liters, respectively. Animal bearing ID 74 obtained lowest index value that had lowest lactation length, lactation milk yield but highest average daily milk yield as 47.00 days, 225.37 liters and 4.80 liters, respectively. Genetic index value by using breeding value of particular trait for milk traits ranged from -1812.49 to 2870.21 . Animal bearing ID 196 obtained highest index value and ID 229 obtained lowest index value. 


\section{DISCUSSION}

Discussions on results found in the study are presented below in different subheadings.

\section{Heritability $\left(\mathbf{h}^{2}\right)$}

\section{Growth traits}

Estimated heritability for birth weight was slightly higher than the value obtained by Afroz et al. (2011) found from RCC, Rabeya et al. (2009) found from RCC, Deb (2004) found from Jersey x Local, Stamer et al. (2004) found from Holstein calves, Bhuiyan (1999) found from Friesian $x$ Local as $0.48 \pm 0.04,0.497 \pm 0.051,0.48 \pm 0.04$, 0.63 and $0.64 \pm 0.56$, respectively. This result is slightly lower than the results obtained by Afroz et al. (2011) found from RCC, Rabeya et al. (2009) found from RCC, Stamer et al. (2004) found from Holstein calves as $0.47 \pm 0.06,0.47 \pm 0.06$ and 0.50 , respectively. Afroz et al. (2011) found from RCC, Rabeya et al. (2009) found from RCC lower heritability for pre-weaning daily gain of calves compared with the results of present study as $0.48 \pm 0.06,0.50 \pm 0.05$ and $0.49 \pm 0.07$, respectively.

\section{Milk production traits}

This result is more or less similar with the results obtained by Deb (2004) who found heritability for lactation length as $0.48 \pm 0.12,0.49 \pm 0.15$ and $0.49 \pm 0.11$ for Friesian $\mathrm{x}$ Local (FN x LO), Jersey x Local (JR x LO) and Local (LO), respectively. Estimated heritability for lactation length was lower than the value obtained by Iqbal (2005) found from FN x LO and JR x LO. This result is consistent with the results obtained by Shakhawat (2006) found from crossbred cattle and Deb (2004) found from Local cattle as $0.43 \pm 0.50$ and $0.45 \pm 0.03$, respectively. Estimated heritability for lactation milk yield was higher than the value obtained by Alam et al. (2007) found from RCC, Balieiro et al. (2003) found from Gir cattle and Choudhary et al. (2003) found from Sahiwal cows as $0.27 \pm 0.11,0.31 \pm 0.09,0.25-0.27$ and $0.27 \pm 0.17$, respectively. This result is consistent with the results obtained by Munim et al. (2006) found from crossbred cattle and Hossain et al. (2002a) found from Local cattle as $0.33 \pm 0.11$ and 0.28 , respectively. Das et al. (2003) found from Pabna Milking cattle higher heritability for daily milk yield as $0.43 \pm 0.27$. Ibrahim et al. (2012) found from Holstein cows, Choudhary et al. (2003) found from Sahiwal cows obtained lower heritability for average daily milk yield compared to the present study as $0.17 \pm 0.14$, $0.20 \pm 0.07$ and $0.27 \pm 0.17$, respectively.

\section{Breeding values and ranking of animals}

\section{Growth traits}

This result is lower than the results obtained by Afroz et al. (2011) found from RCC and Atil et al. (2005) found from Holstein calves who found breeding value for birth weight as -3.9438 to 5.8998 and -4.10 to 5.11 , respectively. But higher than the results obtained by Alam et al. (2007) found from RCC and Shakhawat (2006) found 
from Pabna Milking as -1.494 to 2.782 and $-0.101 \pm 0.05$, respectively. This result is higher than the result obtained by Atil et al. (2005) found from Holstein calves who found breeding value for weaning weight as -0.10 to 5.11. Afroz et al. (2011) found better breeding value for nine month weight of RCC as -16.8767 to 38.1598.The breeding value for pre-weaning daily gain was ranged from -49.7487 to 82.3983 . This result is lower than the result obtained by Afroz et al. (2011) found from RCC as -66.8323 to 144.3421 . However, such comparison of breeding values and ranking of the animals based on estimated breeding values are not comparable with others in real sense.

\section{Milk production traits}

The breeding value for lactation length was ranged from -61.7492 to 52.2508 . This result is higher than the result obtained by Alam et al. (2007) found from RCC as 14.660 to 25.513 . The breeding value for lactation milk yield was ranged from 163.7303 to 186.0424 . This result is higher than the results obtained by Alam et al. (2007) found from RCC and Shakhawat (2006) found from Pabna Milking as -51.924 to 79.687 and $12.077 \pm 2.81$, respectively. The breeding value for average daily milk yield was ranged from -0.5449 to 0.6695 .

\section{CONCLUSION}

Data used in the present study were collected from the Nucleus Herd and Community Herd of Red Chittagong Cattle (RCC) established through United States Department of Agriculture funded RCC project under the Department of Animal Breeding and Genetics, Bangladesh Agricultural University, Mymensingh, Bangladesh. The high estimates of heritability except average daily milk yield, indicate that genetic improvement of these traits can be achieved through selection and breeding. Therefore, selection of individuals based on their own performance may be effective. These index values of the animals can well be used for selecting RCC considering all studied traits together and can be applied in similar animal improvement situations. It may be concluded that heritability, breeding value and index value estimation of some economically important traits of RCC may have an immense worth in selection and breeding program for their genetic improvement.

\section{ACKNOWLEDGMENT}

We are grateful to the USDA funded RCC Project of the Department of Animal Breeding \& Genetics, BAU, Mymensingh for the having the opportunity to conduct research and also grateful to the farmers of RCC community herd Char Jailkhana under Mymensingh division . 


\section{REFERENCES}

Afroz, M.A., Hoque, M.A. and Bhuiyan, A.K.F.H. (2011). Estimation of heritability for growth traits of Red Chittagong cattle in a nucleus herd. The Bangladesh Veterinarian, 28(1): $39-46$.

Alam, M., Bhuiyan, A.K.F.H., Ali, A. and Mamun, A. (2007): Genetic analysis of birth weight and milk production of Red Chittagong Cattle of Bangladesh. Bangladesh Journal of Animal Science, 36 (1\&2): 24-32.

Atil, H., Khattab, A.S. and Badawy, L. (2005). Genetic parameter of birth and weaning weights for Friesian calves by using an animal model. Archive fuer Tierzucht, Dummerstorf, 48(3): 261-269.

Balieiro, E.S., Pereira, J.C.C., Verneque, R.S., Balieiro, J.C.C. and Valente, J. (2003). Estimates of heritability and genetic relationship between reproductive traits and milk yield of Gir cattle. Arquivo Brasileiro de Medicina Veterinariae Zootecnia, 55(1): 85-91.

Bhuiyan, A.K.F.H. (2004). Study on the status, trends, utilization and performance of FAnGR and their wild relatives. Consultant's report, National Consultant, International Livestock Research Institute.

Bhuiyan, A.K.F.H., Dietl, G. and Klautschck, G. (2003). Genetic trends in the development of cross breeding system in beef breeding. Journal of Bangladesh Agricultural University, 10 (1): 49-61.

Bhuiyan, M.S.A. (1999). Estimation of genetic parameters for some economic traits of dairy cattle. MS Thesis, Department of Animal Breeding and Genetics, Bangladesh Agricultural University, Mymensingh, Bangladesh.

Bhuiyan, M.S.A., Bhuiyan, A.K.F.H., Yoon, D.H., Jeon, J.T., Park, C.S. and Lee, J.H. (2007). Mitochondrial DNA diversity and origin of Red Chittagong Cattle. Proceeding of the $15^{\text {th }}$ Plant and Animal Genome Conference, 13-17 January, 2007, San Diego. California, USA. pp. 126.

Choudhary, V., Kothekar, M.D., Raheja, K.L., Kasturiwale, N.N., Khire, D.W. and Kumar, P. (2003). Genetic evaluation of first lactation traits in Sahiwal cattle using restricted maximum likelihood technique. Asian Australasian Journal of Animal Sciences, 16(5): 639-643.

Das, P.K., Ali, S.Z., Islam, A.B.M.M. and Roy, B.K. (2003). A comparative study of productive and reproductive performance and estimates of heritability for economic traits in different genetic groups of cattle available at Baghabarighat Milk Pocket Area of Bangladesh. Online Journal of Biological Science, 3(8): 726-740.

Deb, G.K. (2004). Estimation of genetic parameters for some quantitative traits in dairy cattle of Bangladesh. MS Thesis, Department of Animal Breeding and Genetics, Bangladesh Agricultural University, Mymensingh, Bangladesh.

Habib, M.A., Afroz, M.A. and Bhuiyan, A.K.F.H. (2010). Lactation performance of Red Chittagong Cattle and effects of environmental factors. TheBangladesh Veterinarian, 27 (1): 18-25.

Habib, M.A., Bhuiyan, A.K.F.H., Bhuiyan, M.S.A. and Khan, A. (2003). Performance of Red Chittagong Cattle in Bangladesh Agricultural University Dairy Farm. Bangladesh Journal of Animal Science, 32 (1\&2): 101-108. 
Hossain, K.B., Takayanagi, S., Miyake, T., Moriya, K., Bhuiyan, A.K.F.H. and Sasaki, Y. (2002a): Statistical genetic studies on cattle breeding for dairy productivity in Bangladesh: I. Genetic improvement for milk performance of local cattle populations. AsianAustralasian Journal of Animal Sciences, 15(5): 627-632.

Eid, I.I., Elsheikh, M.O. and Yousif, I.A. (2012). Estimation of Genetic and Non-Genetic Parameters of Friesian Cattle. Journal of Agricultural Science, 4(4): 95-102.

Munim, T., Hussain, S.S., Hoque, M.A. and Khandoker, M.A.M.Y. (2006). Genetic and nongenetic effects on productive and reproductive traits of different genetic groups of cows. Bangladesh Journal of Animal Science, 35: 1-12.

Rabeya, T., Bhuiyan, A.K.F.H., Habib, M.A. and Hossain, M.S. (2009). Phenotypic and genetic parameters for growth traits in Red Chittagong Cattle of Bangladesh. Journal of Bangladesh Agricultural University, 7(2): 265-271.

Shakhawat, H. (2006). Genetic evaluation of productive and reproductive traits of cows at Baghabarighat milk shed area in Bangladesh. Ph.D. Thesis, Department of Animal Breeding and Genetics, Bangladesh Agricultural University, Mymensingh, Bangladesh.

Stamer, E., Hafez, S., Junge, W. and Kalm, E. (2004). Genetic parameters of birth weight and weaning weight of Holstein female calves. Zuchtungskunde, 76(3): 188-195. 